\title{
EDITORIAL
}

\section{Rural medicine 'cooking up' longitudinal integrated clerkships}

\section{AUTHORS}

Lucie Walters ${ }^{1}$ FACRRM, Professor Postgraduate Medical Education *, lucie.walters@flinders.edu.au

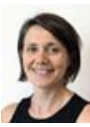

Leesa Walker² FRACGP, Clinical Educator Rural Medicine, leesa.walker@flinders.edu.au

\section{CORRESPONDENCE}

*Prof Lucie Walters lucie.walters@flinders.edu.au

\section{AFFILIATIONS}

1, 2 Flinders Rural Health South Australia, PO Box 3570, Mount Gambier, SA 5290, Australia

\section{PUBLISHED}

22 September 2018 Volume 18 Issue 3

\section{HISTORY}

RECEIVED: 18 September 2018

REVISED: 18 September 2018

ACCEPTED: 18 September 2018

\section{CITATION}

Walters L, Walker L. Rural medicine 'cooking up' longitudinal integrated clerkships. Rural and Remote Health 2018; $18: 5099$. https://doi.org/10.22605/RRH5099

Except where otherwise noted, this work is licensed under a Creative Commons Attribution 4.0 International Licence

\section{FULL ARTICLE:}

As we approach the Muster medical education conference in Mount Gambier in October (http://muster2018.com), this article celebrates the contribution of rural programs to the longitudinal integrated clerkship (LIC) movement by examining the contributions of articles published online in Rural and Remote Health to the LIC discourse. Over the past 20 years, the International Consortium of Longitudinal Integrated Clerkships has encompassed prestigious urban sandstone medical schools in the USA and emerging rural programs in Australia1.

Asking how rural medical programs have contributed to the LIC movement in medical education can be compared to asking how rural cooks have contributed to haute cuisine, traditionally the realm of chefs. A chef is (usually) understood to have standing in the culinary profession through qualifications and apprenticeship years working in the open and complex environments of grand restaurant kitchens ${ }^{2}$. Cooks can be considered the practical kitchen workers who provide the 'how to' advice and pragmatic action required to just get on and feed the family. Bridging this divide is rural Australian cook and restaurateur Maggie Beer ${ }^{\mathbf{3}}$, who describes herself as having grown up in a 'food family', then starting a farm shop and later a restaurant in the Barossa Valley in South Australia. Her menu is influenced by 'utilising everything' - first the produce from her own farm and then that of her neighbours.

It is a credit to the Consortium of Longitudinal Integrated Clerkships that country 'cooks' and international 'chefs' have worked together 
to enrich the learning theory and praxis discourse in medical education.

\section{Longitudinal integrated clerkship development}

A description of 'cooking up' LICs in rural Australia can only commence with recognition of medical community of practice - for example in the Riverland and then other rural areas in South Australia that have developed and sustained the parallel rural community curriculum ${ }^{\mathbf{4}}$. This immersion experience, where medical students are based in rural general practice for at least a half-year semester and follow patients and their supervisors through the healthcare system, learning clinical disciplines in an integrated manner, has been reproduced in other areas of Australia ${ }^{4-10}$ and internationally in both developed ${ }^{11,12}$ and developing countries $^{13,14}$.

\section{Social accountability and community engagement}

Where 'chefs' have a relationship with 'food' (in this case a curriculum), 'cooks' can be seen as having knowledge of and responsibility for those they 'feed' (patients, students and clinical teachers). Social accountability for rural LICs specifically seeks to improve recruitment and retention of the medical workforce in low-resource rural areas ${ }^{\mathbf{1 5}}$. The sustainability of longitudinal programs requires the nourishment and support of clinicians ${ }^{\mathbf{1 6}-\mathbf{1 8}}$. Longitudinal placements enable time for meaningful relationships to form between clinicians and students, increasing clinician morale and student satisfaction with training ${ }^{\mathbf{1 0 , 1 8}}$. Rural LICs have also highlighted the importance of recognition and remuneration of clinicians ${ }^{\mathbf{1 2}} \mathbf{1 7}, \mathbf{1 9}$. The rural LIC literature has contributed to the discourse about bringing clinicians around the medical education table to commune with each other and build trust with academic organisations, and to develop networks of rural medical teachers to grow their own workforce $4, \mathbf{1 3}, \mathbf{1 8 , 2 0 , 2 1}$.

Learning is a social process, and out of necessity country cooks routinely seek to share the responsibility for providing meals with those eating them. Rural LICs have engaged meaningfully with, recognised the contributions of and provided for community members $\mathbf{2 1 - 2 3}$. We argue that, particularly in resource-poor areas, rural LICs have led the medical education community engagement agenda to ensure sustainability of medical education programs and the capacity to influence policy ${ }^{\mathbf{2 3 , 2 4}}$. LICs seek to inculcate learners with the Hippocratic attributes of deep human interest, moral mastery of self and conscientious pursuit of knowledge through the medical program continuities of patient care, supervision and curriculum $\mathbf{1}$.

\section{Human interest through engagement}

Students in rural placements witness the often long-term comprehensive and messy relationships between rural general practitioners and their patients. Longitudinal placements enable time for meaningful relationships to form between students and patients ${ }^{\mathbf{1 0}, \mathbf{1 8}}$. Knowing people during their health journeys increases students' understanding of the health system and community healthcare needs $\mathbf{8}^{\mathbf{8} 25}$. In 'country kitchens', student curiosity is nurtured into deep human interest through authentic engagement with patients as people. The LIC academic community of practice has translated this rural phenomenon to metropolitan centres of excellence, adding strength to the discourse around humanism in medical education.

\section{Pursuit of knowledge}

In the television program The Cook and the Chef, Maggie Beer and her co-host, chef Simon Bryant, surprised us by privileging a domestic kitchen situated in a 'local place' over a cosmopolitan but impersonal commercial kitchen $\mathbf{3}^{\mathbf{3}}$ Likewise, rural LICs are seen as strongly embedded in local communities. The LIC movement has brought recognition to rural programs for their community-engaged training, authentic hands-on experiences and interprofessional team approaches ${ }^{\mathbf{7}}$. However, these attributes alone could marginalise rural programs without considerable evidence of academic rigour. Development of clinical reasoning is context dependent ${ }^{\mathbf{2 6}}$. Rural LICs provide both broader clinical learning opportunities and equivalent results in formal examinations ${ }^{\mathbf{6 , 8}}$. Academic rigour has been further enhanced through robust critique and leadership from both rural community and urban hospital LICs.

\section{Mastery of self}

Perhaps more important than the food of a kitchen is its nourishment of people. Rural LICs have actively sought to influence career interests ${ }^{\mathbf{2 7}}$. Meaningful participation in rural healthcare teams and the trust demonstrated by patients and health professionals have increased medical students' sense of belonging and responsibility ${ }^{\mathbf{2 5}}$. Medicine is a stressful profession. Rural LICs provide students with personal development opportunities and increased life experience ${ }^{\mathbf{6}}$. Perhaps more importantly they provide time and space for reflection, contributing to students' ability to manage the stresses of medical training and provision of medical care ${ }^{\mathbf{2 5}}$.

\section{Conclusion}

Through the Consortium of Longitudinal Integrated Clerkships, the contributions of longitudinal relationships, rather than those of rural location, can be separated and celebrated. Using the analogy of country cook and haute cuisine chef, we have argued that rural LICs have contributed significantly and broadly to medical education. Like country cooks, rural LICs have got on with the job locally, perhaps 
without considering their wider impact. Through the Consortium of Longitudinal Integrated Clerkships, their influence has been profound. As Maggie Beer has demonstrated, relationships between urban and rural can be symbiotic, and expertise has no geographical bounds.

\section{REFERENCES:}

1 International Consortium of Longitudinal Integrated Clerkships. Consensus longitudinal integrated clerkship definition. Cambridge, MA: CLIC Meeting, 10-14 November, 2007.

2 Nicolini D, Gherardi S, Yanow (Eds). Knowing in organizations: a practice-based approach. Armonk, NY: ME Sharpe, 2003.

3 Gunders J. Professionalism, place, and authenticity in The Cook and the Chef. Emotion, Space and Society 2008; 1(2): $119-126$. https://doi.org/10.1016/j.emospa.2008.11.001

4 Walters LK, Worley PS, Mugford BV. Parallel Rural Community Curriculum: is it a transferable model? Rural and Remote Health 2003; 3: 236. https://doi.org/10.22605/RRH236 PMid:15882099

5 Baillie S, Matena J, Yerxa J, Newbury J. Rural medical education: five medical students spend a year in rural Port Lincoln, Australia. Rural and Remote Health 2007; 7: 586. https://doi.org/10.22605/RRH586 PMid:17604491

6 Denz-Penhey H, Murdoch J. Reported reasons of medical students for choosing a clinical longitudinal integrated clerkship in an Australian rural clinical school. Rural and Remote Health 2009; 9: 1093. https://doi.org/10.22605/RRH1093 PMid:19335058

7 Birden HH, Wilson I. Rural placements are effective for teaching medicine in Australia: evaluation of a cohort of students studying in rural placements. Rural and Remote Health 2012; 12: 2167. https://doi.org/10.22605/RRH2167 PMid:23157496

8 Sturmberg J, Reid AL, Thacker JL, Chamberlain C. A community based, patient-centred longitudinal medical curriculum. Rural and Remote Health 2003; 3: 210. https://doi.org/10.22605/RRH210 PMid:15877510

9 Morgan S, Smedts A, Campbell N, Sager R, Lowe M. From the bush to the big smoke - development of a hybrid urban community based medical education program in Northern Territory, Australia. Rural and Remote Health 2009; 9: 1175. https://doi.org/10.22605 /RRH1175 PMid:19751095

10 Denz-Penhey H, Shannon S, Murdoch JC, Newbury J. Do benefits accrue from longer rotations for students in Rural Clinical Schools? Rural and Remote Health 2005; 5: 414. https://doi.org/10.22605/RRH414 PMid:15946108

11 Couper I, Worley P, Strasser R. Rural longitudinal integrated clerkships: lessons from two programs on different continents. Rural and Remote Health 2011; 11: 1665. https://doi.org/10.22605/RRH1665 PMid:21449620

12 Bing-You R, Trowbridge R, Kruithoff C, Daggett Jr J, Bing-You R. Unfreezing the Flexnerian Model: introducing longitudinal integrated clerkships in rural communities. Rural and Remote Health 2014; 14: 2944. https://doi.org/10.22605/RRH2944 PMid:25142244

13 Woolley T, Cristobal F, Siega-Sur JJ, Ross S, Neusy AJ, Halili SD, et al. Positive implications from socially accountable, communityengaged medical education across two Philippines regions. Rural and Remote Health 2018; 18: 4264. https://doi.org/10.22605/RRH4264 PMid:29453906

14 Cristobal F, Worley P. Can medical education in poor rural areas be cost-effective and sustainable: the case of the Ateneo de Zamboanga University School of Medicine. Rural and Remote Health 2012; 12: 1835. https://doi.org/10.22605/RRH1835 PMid:22384807

15 Sen Gupta T, Murray R, Hays R, Woolley T. James Cook University MBBS graduate intentions and intern destinations: a comparative study with other Queensland and Australian medical schools. Rural and Remote Health 2013; 13: 2313. https://doi.org/10.22605 /RRH2313 PMid:23751066

16 Walters L, Worley P, Prideaux D, Rolfe H, Keaney C. The impact of medical students on rural general practitioner preceptors. Rural and Remote Health 2005; 5: 403. https://doi.org/10.22605/RRH403 PMid:16283828

17 Worley P, Kitto P. A hypothetical model of the financial impact of student attachment on rural general practice. Rural and Remote Health 2001; 1: 83. https://doi.org/10.22605/RRH83 PMid:15869365

18 Hudson J, Thomson B, Weston K, Knight-Billington P, Weston JHBTK, Knight-Billington P. When a LIC came to town: the impact of longitudinal integrated clerkships on a rural community of healthcare practice. Rural and Remote Health 2015; 15: 3333. https://doi.org /10.22605/RRH3333 PMid:26387868

19 Hudson JN, Weston KM, Farmer E. Medical students on long-term regional and rural placements: what is the financial cost to supervisors? Rural and Remote Health 2012; 12: 1951. https://doi.org/10.22605/RRH1951 PMid:22519409

20 Longenecker R, Schmitz D. Building a community of practice in rural medical education: growing our own together. Rural and Remote Health 2017; 17: 4195. https://doi.org/10.22605/RRH4195 PMid:28342441

21 Strasser R. Community engagement: a key to successful rural clinical education. Rural and Remote Health 2010; 10 : 1543. 
22 Stagg P, Rosenthal D. Why community members want to participate in the selection of students into medical school. Rural and Remote Health 2012; 12: 1954. https://doi.org/10.22605/RRH1954 PMid:22905957

23 Mlambo M, Dreyer A, Dude R, Mapukata N, Couper I, Cooke R. Transformation of medical education through Decentralised Training Platforms: a scoping review. Rural and Remote Health 2018; 18: 4337. https://doi.org/10.22605/RRH4337 PMid:29522688

24 Hays R. Guiding principles for successful innovation in regional medical education development. Rural and Remote Health 2006; 6: 516. https://doi.org/10.22605/RRH516 PMid:16438638

25 Mader E, Roseamelia C, Lewis S, Arthur ME, Reed E, Germain LJ. Clinical training in the rural setting: using photovoice to understand student experiences. Rural and Remote Health 2016; 16: 3877. Available: https://doi.org/10.22605/RRH3877 PMid:27179591

26 Campbell D, Walters L, Couper I, Greacen J. What are they thinking? Facilitating clinical reasoning through longitudinal patient exposure in rural practice. Rural and Remote Health 2017; 17: 4162. https://doi.org/10.22605/RRH4162 PMid:29248011

27 Stagg P, Greenhill J, Worley PS. A new model to understand the career choice and practice location decisions of medical graduates. Rural and Remote Health 2009; 9: 1245. https://doi.org/10.22605/RRH1245 PMid:19943714

This PDF has been produced for your convenience. Always refer to the live site https://www.rrh.org.au/journal/article/5099 for the Version of Record. 